\title{
Vitamin A and human immunodeficiency virus infection
}

\author{
BY RICHARD D. SEMBA \\ Ocular Immunology Service, Johns Hopkins University School of Medicine, Suite 700, \\ 550 North Broadway, Baltimore, MD 21205, USA
}

By the year 2000 there will be an estimated twenty-six million individuals infected with human immunodeficiency virus (HIV) (Quinn, 1996). About four to five million cumulative cases are expected among children by the year 2000. The areas hardest-hit by the acquired immune deficiency syndrome (AIDS) epidemic are sub-Saharan Africa, south Asia, and south-east Asia, where the prevalence of micronutrient deficiencies is generally higher. More than $90 \%$ of new HIV infections are now occurring in developing countries. Although HIV infection is characterized by a variety of micronutrient deficiencies and wasting (Beach et al. 1992; Kotler \& Grunfeld, 1995), the relationship between nutritional status and clinical outcome in HIV infection is not well understood. Vitamin A plays a major role in normal immune function (Semba, 1994), and as early as the 1960s it was acknowledged that 'no micronutrient deficiency is more synergistic with infection than that of vitamin A' (Scrimshaw et al. 1968). The present review focuses on the relationship between vitamin A, immunity, and HIV infection.

\section{VITAMIN A AND IMMUNITY}

Vitamin A deficiency is a nutritionally-acquired immunodeficiency disorder characterized by widespread pathological alterations of mucosal epithelia of the respiratory, gastrointestinal, and genito-urinary tracts, impaired antibody responses to protein antigens, altered cell-mediated immunity, and alterations in T-cell subsets (Semba et al. 1992, 1993b; Wiedermann et al. 1993; Zhao \& Ross, 1995; Cantorna et al. 1996; Ross, 1996). Vitamin A, through its active metabolite, all-trans retinoic acid, regulates genes through nuclear receptors in the steroid and thyroid hormone superfamily (Ross \& Ternus, 1993). The genes relevant to immunity which are regulated by vitamin $\mathrm{A}$ have not been completely characterized, but probably include those for interleukin-4, interferon- $\gamma$ (Cantorna et al. 1996), interleukin-2 receptor (Sidell et al. 1993), and others. Growth and activation of T and B cells are dependent on vitamin A (Buck et al. 1990; Garbe et al. 1992), and vitamin A supplementation is associated with increases in circulating lymphocytes, including CD4 T-cells and natural killer cells, suggesting that lymphopoiesis is enhanced by vitamin A (Semba et al 1993b; Ross, 1996).

The potential consequences of the immunodeficiency associated with vitamin $A$ deficiency have been shown in longitudinal studies of preschool children which were conducted in Indonesia in the late 1970s. These studies demonstrated that children with mild vitamin A deficiency were at higher risk of respiratory and diarrhoeal disease and higher mortality (Sommer et al. 1983, 1984). A series of community-based clinical trials of vitamin A supplementation for preschool children soon followed in Indonesia, India, Nepal, Sudan, and Ghana, which showed overall that vitamin A supplementation or fortification reduced child mortality by about 20-30\% (Beaton et al. 1993). Further analysis showed that vitamin A reduces the severity of diarrhoeal disease but seems to have little effect on respiratory disease (The Vitamin A and Pneumonia Working Group, 1995). High-dose vitamin A supplementation was also shown to reduce morbidity and mortality in 
children with acute, complicated measles (Hussey \& Klein, 1990; Coutsoudis et al. 1991). These clinical trials demonstrate that vitamin $\mathrm{A}$ is an immune enhancer and suggest that vitamin A may have other therapeutic applications as a therapy for HIV infection.

\section{PATHOGENESIS OF VITAMIN A DEFICIENCY}

Factors which may contribute to the development of vitamin A deficiency include: low intake of vitamin A-containing foods, anorexia of chronic disease, diarrhoea and malabsorption, concomitant protein-energy malnutrition, liver disease, abnormal urinary losses of vitamin A during infections, the acute-phase response, and accelerated utilization of vitamin A. In many developing countries where HIV infection is common, the intake of vitamin A-containing foods may be marginal. Oesophageal candidiasis, cryptococcal meningitis, and progressive multifocal leukoencephalopathy during HIV infection are associated with anorexia and wasting (Nahlen et al. 1993). Diarrhoea and malabsorption syndromes are common during HIV infection and can be caused by a wide variety of pathogens, including cryptosporidiosis and isosporiasis. Fat malabsorption has been reported in HIV-infected individuals and may interfere with vitamin A absorption and metabolism.

Protein-energy malnutrition increases the risk of developing vitamin A deficiency (Smith et al. 1973), probably because vitamin A transport relies on a carrier-protein complex of retinol-binding protein and transthyretin. Hepatitis appears to interfere with the metabolism of vitamin A (Smith \& Goodman, 1971), and hepatitis B and C are common in many HIV-infected populations. During the acute-phase response, retinol-binding protein may break off from the carrier complex of transthyretin and retinol, allowing abnormal glomerular losses of vitamin A which may reach several times the required daily allowance for vitamin A (Stephensen et al. 1994; Alvarez et al. 1995). Individuals with HIV infection and AIDS have been shown to have higher abnormal urinary losses of vitamin A compared with controls (Silveira et al. 1996). Whether infections accelerate the utilization of vitamin A is not clear; however, the depletion of hepatic vitamin A was shown to be increased in children who incidentally contracted chickenpox during a vitamin A dosing study (Campos et al. 1987). It is unknown whether the virulence of HIV itself may influence vitamin A status.

\section{PREVALENCE OF VITAMIN A DEFICIENCY DURING HUMAN IMMUNODEFICIENCY VIRUS INFECTION}

The prevalence of vitamin A deficiency may vary widely, depending upon the population. Serum or plasma vitamin A levels have been used as the main indicator of vitamin A status in most of these investigations. In a hospital-based, cross-sectional study of fifty-nine adults with AIDS in New York City who were not taking vitamin supplements, $20 \%$ had serum vitamin A levels $<0.70 \mu \mathrm{mol} / 1$ (Karter et al. 1995). A study of 100 asymptomatic, HIV-infected homosexual men in Miami showed that $18 \%$ had serum vitamin A levels $<1.23 \mu \mathrm{mol} / \mathrm{l}$, which were considered to be in the marginal range (Beach et al. 1992). In forty-seven HIV-infected adults with wasting syndrome in Portland, Oregon, $14 \%$ had serum vitamin A levels $<1.75 \mu \mathrm{mol} / 1$ (Coodley et al. 1993). A study of seventy-four HIVinfected pregnant women in Thailand showed mean vitamin A levels of $1.23 \mu \mathrm{mol} / \mathrm{l}$. Direct comparisons of the vitamin A status in these various studies is problematic because of the different cut-offs of serum or plasma vitamin A used to define vitamin A deficiency in adults. 
We investigated the vitamin A status of different HIV-infected populations which included injection drug users, homosexual men, adults in Uganda, pregnant women in Malawi, pregnant women in the USA, and lactating women in Haiti. Comparison of vitamin A levels in these different populations is useful because it may provide clues to the epidemiology and pathogenesis of vitamin A deficiency during HIV infection. Plasma vitamin A levels were measured in $284 \mathrm{HIV}$-infected injection drug users from a cohort study in Baltimore, Maryland (AIDS Linked to Intravenous Experiences, ALIVE study; Vlahov et al. 1991). The frequency distribution of vitamin A levels is shown in Fig. 1. In our studies in adults we have defined vitamin A deficiency as consistent with serum or plasma vitamin A levels $<1.05 \mu \mathrm{mol} / 1$, a level at which some individuals may have impairment of biological function (Pilch, 1987). Using this criterion, about $29 \%$ of HIVinfected injection drug users had plasma vitamin A levels consistent with deficiency in adults. Data from the first National Health and Nutrition Examination Survey show that in the normal adult population in the USA, 1-3\% of adults have serum vitamin A levels $<1.05 \mu \mathrm{mol} / 1$ (Pilch, 1987). In a study of $311 \mathrm{HIV}$-infected homosexual men (Study to Help the AIDS Research Effort, SHARE) in Baltimore and Washington, DC, the frequency distribution of plasma vitamin A levels suggested that this population was replete in vitamin A (Fig. 2). The frequency distribution is flatter and shifted to the right in this population of homosexual men. Serum vitamin A levels were measured in 522 HIVinfected adults followed in a large cohort study in an outpatient clinic at Old Mulago Hospital, Kampala, Uganda (Fig. 3). The adults in Uganda were HIV seropositive and purified-protein-derivative positive or negative with no radiological evidence of tuberculosis.

Pregnant and lactating women are generally at higher risk of vitamin A deficiency. The frequency distribution of serum vitamin A levels in $474 \mathrm{HIV}$-infected pregnant women followed in the antenatal clinic at Queen Elizabeth Central Hospital, Blantyre, Malawi is shown in Fig. 4. Of these women $63.3 \%$ had serum vitamin A levels consistent with vitamin A deficiency. In comparison, serum vitamin A levels from $513 \mathrm{HIV}$-infected pregnant women from the Womens and Infants Transmission Study (WITS), a multicentre study in the USA are shown in Fig. 5 (S. Landesman, D. Burns, D. Cotton, G. Fitzgerald, M. G. Fowler, R. Hershow, J. Pitt, R. D. Semba and C. Zorilla, unpublished results). Of the women in WITS, $22 \%$ had serum vitamin A levels consistent with vitamin A deficiency.

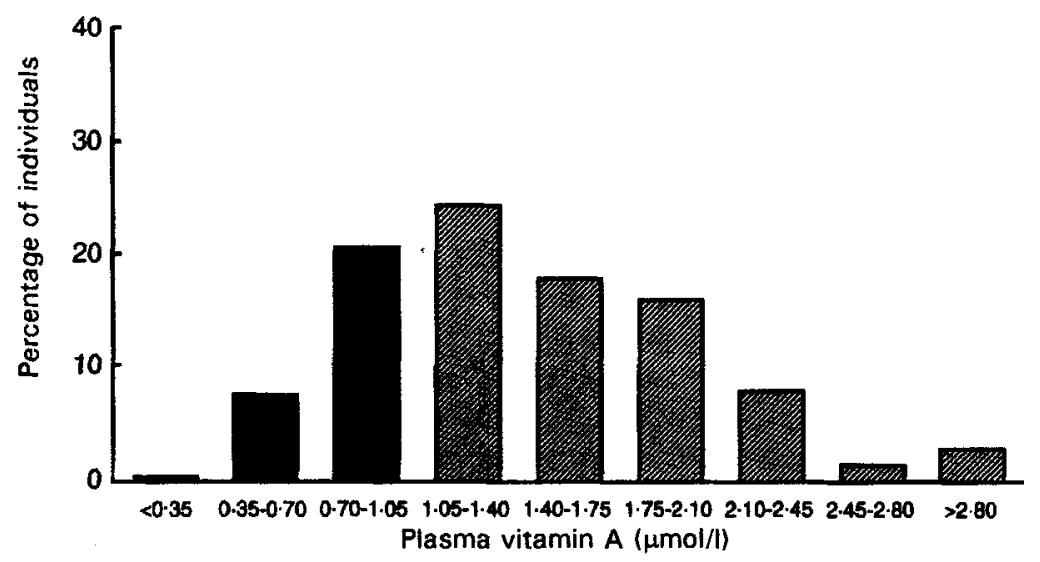

Fig. 1. Frequency distribution of vitamin A levels in 284 HIV-seropositive injection drug users in Baltimore, Maryland.

(G), Proportion of individuals with vitamin A levels $<1.05 \mu \mathrm{mol} / 1$. 


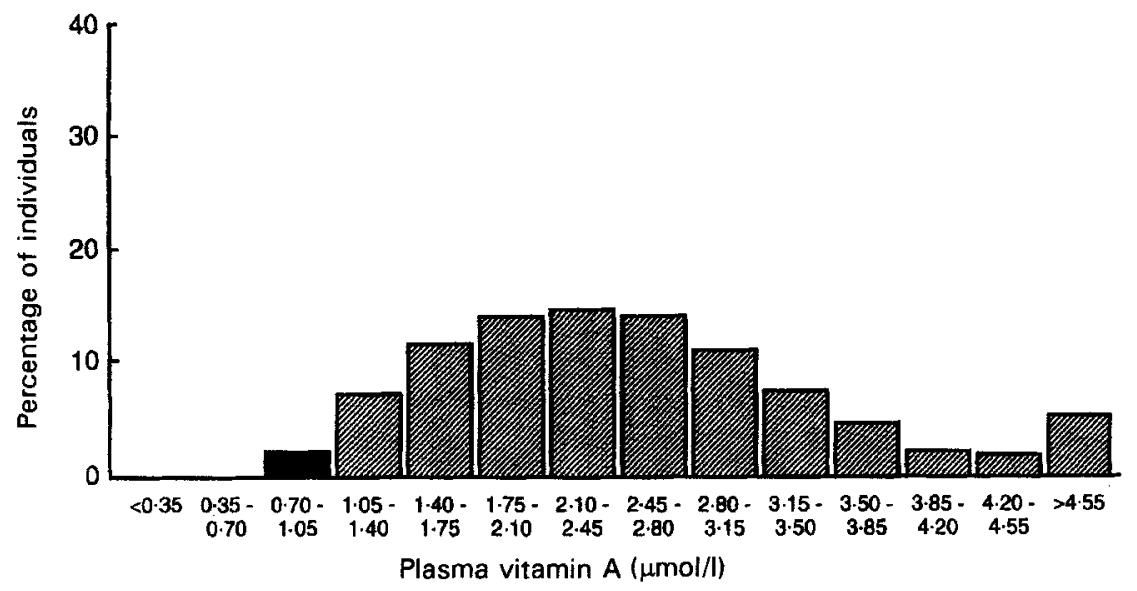

Fig. 2. Frequency distribution of vitamin A levels in 311 HIV-seropositive homosexual men in a cohort from Baltimore, Maryland and the Washington, DC area. (E), Proportion of individuals with vitamin A levels $<1.05 \mu \mathrm{mol} /$.

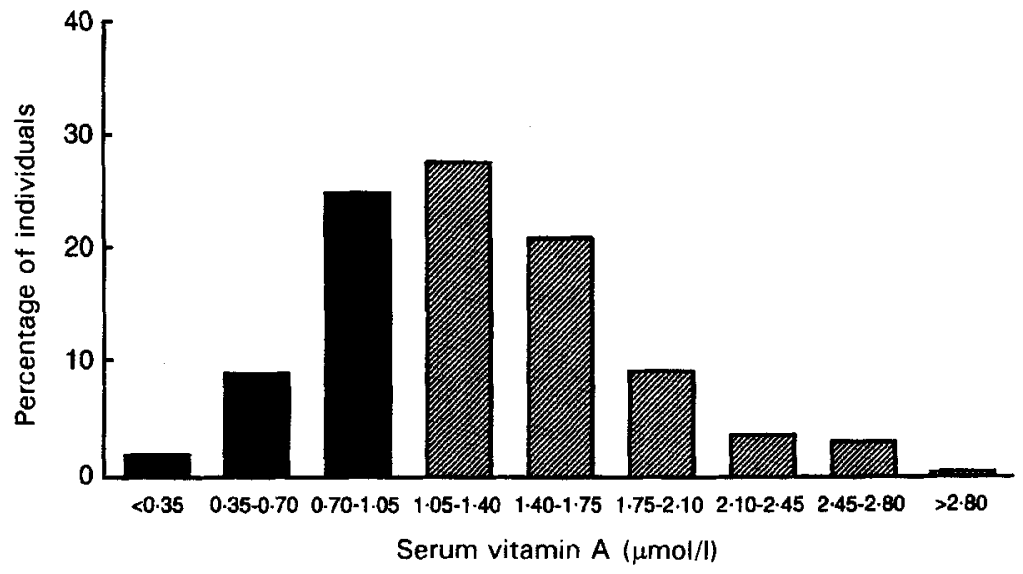

Fig. 3. Frequency distribution of vitamin A levels in 522 HIV-seropositive adults from an outpatient clinic of the Old Mulago Hospital, Kampala, Uganda. (ם), Proportion of individuals with vitamin A levels $<1.05 \mu \mathrm{mol} /$.

Overall, the vitamin A status of HIV-infected pregnant women in the USA was better than that in Africa. Vitamin A levels were measured in 126 HIV-infected lactating women at 6 months post-partum who were being followed in an outpatient clinic in Cite Soleil, Port $\mathrm{Au}$ Prince, Haiti (J. S. Coberly, R. D. Semba, N. Halsey, J. Desormeaux, D. Jules-Joseph, P. A. Carrenard, M. McBrien, R. Boulos and A. J. Ruff, unpublished results; Fig. 6). Over $75 \%$ of these lactating women had vitamin A levels consistent with vitamin A deficiency.

Comparison of the frequency distributions of vitamin A levels in these six different populations allows some possible generalizations. First, HIV-infected adults from developing countries had lower vitamin A levels than HIV-infected adults in the USA. Such an observation might be expected because the intake of vitamin A-rich or vitamin Afortified foods is lower in developing countries. Second, HIV-infected injection drug users from inner city Baltimore had lower vitamin A levels than HIV-infected homosexual men 


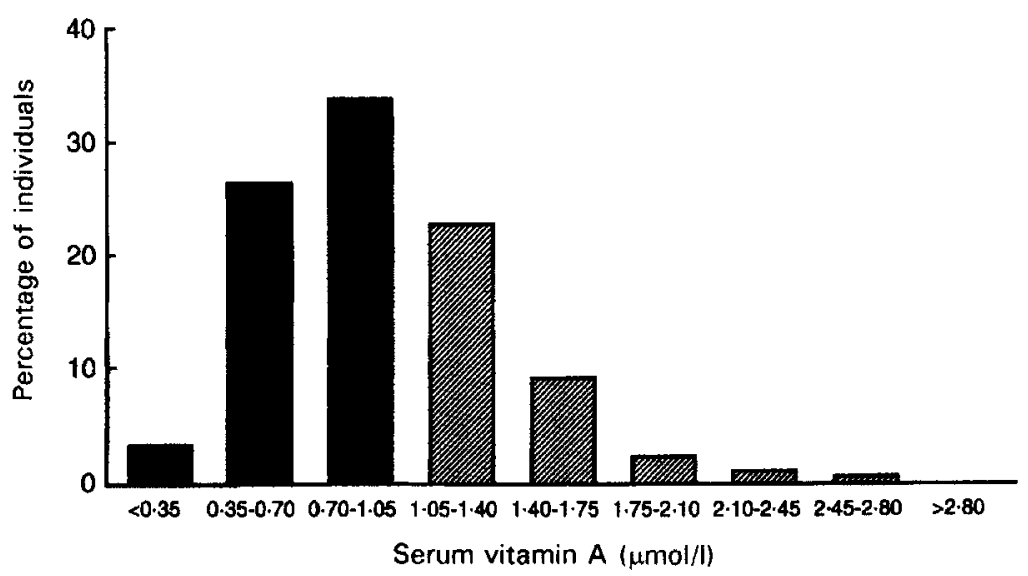

Fig. 4. Frequency distribution of vitamin A levels in $474 \mathrm{HIV}$-seropositive women seen in the antenatal clinic of the Queen Elizabeth Central Hospital, Blantyre, Malawi. (E), Proportion of individuals with vitamin A levels $<1.05 \mu \mathrm{mol} /$ 1 .

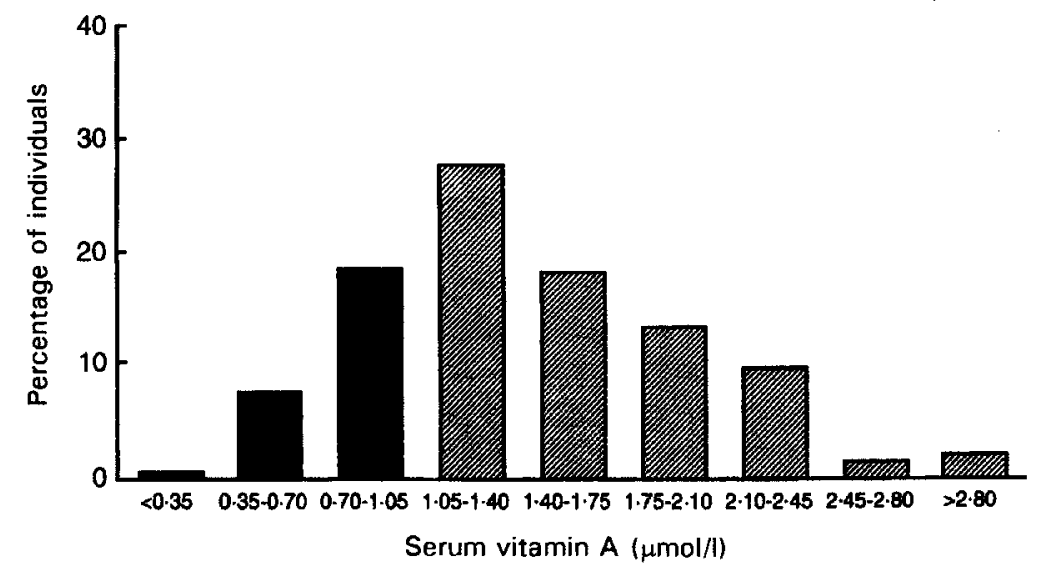

Fig. 5. Frequency distribution of vitamin A levels in 513 HIV-seropositive women in a multicentre cohort study in the USA (Women and Infants Transmission Study). (ロ), Proportion of individuals with vitamin A levels $<1.05 \mu \mathrm{mol} / 1$.

from the same region. Dietary and socio-economic factors probably account for these differences. Third, many of the homosexual men were taking vitamin supplements (Tang $e t$ al. 1993), which suggests that supplementation reduces the risk of having a low vitamin A level, in spite of opportunistic infections associated with HIV infection. Finally, it is well known that pregnancy and lactation are high-risk periods for vitamin A deficiency in women, and these findings show an alarmingly high prevalence of vitamin A deficiency among HIV-infected pregnant and lactating women.

\section{VITAMIN A DEFICIENCY AND MORTALITY}

Vitamin A deficiency and HIV infection constitute a combined immunodeficiency syndrome which might be expected to have adverse clinical consequences. Vitamin A 


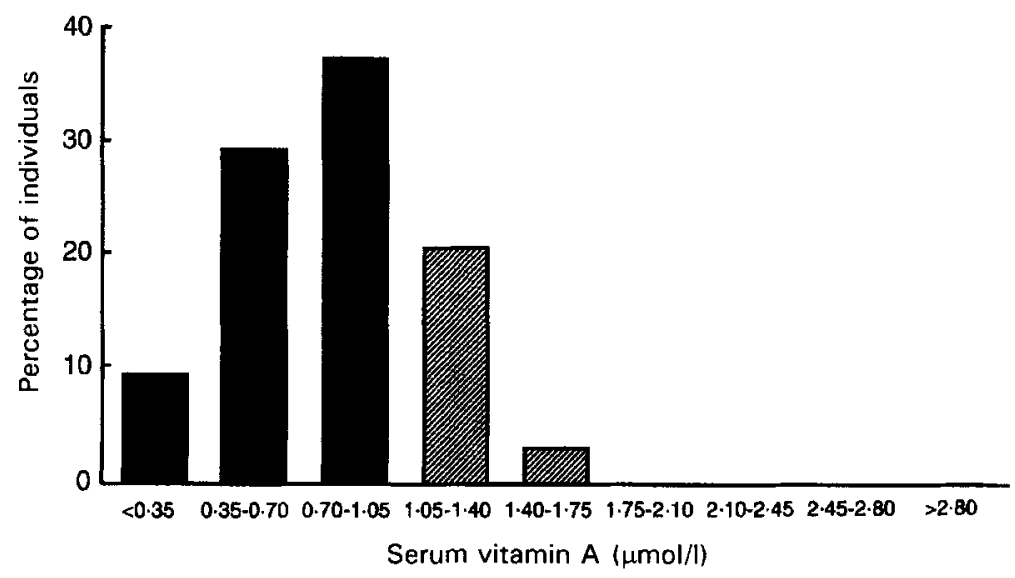

Fig. 6. Frequency distribution of vitamin A levels in 126 HIV-seropositive lactating women from Cite Soleil, Port Au Prince, Haiti. (D), Proportion of individuals with vitamin A levels $<1.05 \mu \mathrm{mol} / \mathrm{l}$.

deficiency was shown to be associated with increased mortality in a longitudinal study of injection drug users in Baltimore (Semba et al. 1993a). Adults with vitamin A deficiency had decreased survival by about 1 year. This was corroborated by a larger nested casecontrol study within the ALIVE study which showed that vitamin A deficiency was an independent risk factor for mortality and was associated with a four-fold increased risk of death (Semba et al. 1995a). Three other studies from Haiti (Rwangabwoba et al. 1996), Uganda, and Miami have recently confirmed the association between vitamin A deficiency and increased mortality during HIV infection, with relative risks for mortality estimated between 2 and 4 in these different studies. In addition, further follow-up in the cohort of HIV-infected women in Malawi shows that women in the lowest quartiles of serum vitamin A levels had significantly higher mortality (Semba, 1997). Although data from five different study populations around the world now demonstrate a similar relationship between vitamin A deficiency and increased mortality in adults, it is unknown whether vitamin A supplementation will reduce mortality in HIV-infected adults.

\section{VITAMIN A DEFICIENCY AND VERTICAL TRANSMISSION OF HUMAN IMMUNO- DEFICIENCY VIRUS}

The period of highest risk for vitamin A deficiency in women is during pregnancy, when there are increased demands for vitamin A because of the growing fetus. Epidemics of nightblindness, the earliest clinical manifestation of vitamin A deficiency, were common among pregnant women in Europe in the nineteenth century and early part of this century before dietary improvements (Birnbacher, 1928). Nightblindness was so common in pregnant women near Bombay, India, that it was considered to be a normal symptom of pregnancy, along with morning sickness (Dixit, 1966). It has been shown recently in a case-control study in Nepal that pregnant women with nightblindness have significantly higher infectious disease morbidity than matched controls without nightblindness (Christian et al. 1996). As shown in Figs. 4 and 6, vitamin A deficiency has the highest prevalence among pregnant and lactating women. The major factor contributing to the high prevalence of nightblindness during pregnancy is probably insufficient intake of vitamin Arich foods. 
The rates of vertical transmission (mother-to-child transmission) of HIV generally are estimated to be $10-40 \%$, with rates being higher in developing countries. Prolonged duration of breast-feeding in developing countries was generally thought to account for the higher rates in areas such as sub-Saharan Africa, because HIV may be present in breast milk. Other known risk factors for vertical transmission include prolonged duration of rupture membranes at delivery (Landesman et al. 1996), high maternal HIV viral load (Dickover et al. 1996), low maternal CD4 count, and chorioamnionitis (Temmerman et al. 1995).

Given the potential effects of vitamin A deficiency on immunity, and the high prevalence of vitamin A deficiency during pregnancy, we investigated the relationship between vitamin A deficiency and vertical transmission. HIV-infected pregnant women in Malawi who were vitamin A-deficient were three to four times more likely to transmit HIV to their infants (Semba et al. 1994). There was a strong association between low maternal vitamin A levels and increased vertical transmission after controlling for CD4 count, maternal age, and maternal BMI. Infant mortality was higher among those born to vitamin A-deficient HIV-infected pregnant women, reaching $93 \%$ mortality among infants born to the most-severely-vitamin A-deficient women (Semba et al. 1995b). Further studies in Malawi (Semba, unpublished results) have recently shown that HIV-seronegative pregnant women with serum vitamin A levels consistent with deficiency also have significantly higher infant mortality. Thus, the findings of maternal vitamin A deficiency and increased infant mortality are consistent among both HIV-seropositive and -seronegative women.

Whether low serum vitamin A levels are a 'marker' for increased vertical transmission or are causally involved is unknown. In experimental animal models, vitamin A deficiency during pregnancy is associated with chorioamnionitis (Noback \& Takahashi, 1978), a placental infection which is a known risk factor for vertical transmission. In addition, animals made deficient in vitamin A during pregnancy have low birth weight and high mortality of offspring, which is consistent with the findings from human studies. Vitamin A deficiency may have serious consequences for immune function in the mother as well as immune development in the fetus, but these biological mechanisms have not been characterized. The association between maternal vitamin A deficiency and vertical transmission has been confirmed in Rwanda (Semba, unpublished results), Haiti (J. S. Coberly, R. D. Semba, N. Halsey, J. Desormeaux, D. Jules-Joseph, P. P. Carrenard, M. McBrien, R. Boulos and A. J. Ruff, unpublished results), and in Baltimore and New York City (Greenberg et al. 1996). A recent study from Kenya shows that HIV-infected women with vitamin A deficiency have a greatly increased risk of HIV load in breast milk, which suggests a possible mechanism for increased transmission through breast-feeding (Nduati et al. 1995).

\section{VITAMIN A DEFICIENCY AND VIRAL LOAD}

High circulating HIV viral load has been shown to be a risk factor for HIV progression (Ferre et al. 1995) and vertical transmission (Dickover et al. 1996). The relationship between serum vitamin A levels and viral load is of potential importance, because the HIV genome contains a retinoic acid response element in the long terminal repeat (Orchard $e t$ al. 1993), and all-trans retinoic acid, the active metabolite of vitamin A, has been shown to influence HIV replication (Poli et al. 1992; Turpin et al. 1992). In a cross-sectional study of 284 HIV-infected injection drug users from the ALIVE cohort, no relationship was found between plasma vitamin A levels and viral load (Semba, unpublished results). In a study of homosexual men from the Multicentre AIDS Cohort Study, there was no relationship 
between serum vitamin A levels and viral load (Semba, unpublished results). A randomized, double-masked, placebo-controlled clinical trial of high-dose vitamin A supplementation for $120 \mathrm{HIV}$-infected adults shows that vitamin A supplementation has no effect on viral load (Semba, unpublished results). In a related study, a phase $\mathrm{V} / \mathrm{II}$ trial of alltrans retinoic acid treatment for Kaposi's sarcoma showed no effect of retinoic acid on HIV p-24 antigenaemia, suggesting that retinoic acid had no effect on viral load (Bailey $e t$ al. 1995).

These studies suggest that vitamin A levels and viral load are independent risk factors during HIV infection, and that vitamin A deficiency is not a marker for viral load. Highdose vitamin A supplementation does not seem to have an effect on viral load levels, and this finding has implications for clinical trials of antenatal supplementation of vitamin $A$ as a strategy to reduce mother-to-child transmission of HIV. These findings refute the idea that vitamin A supplementation would work in the same manner as an anti-retroviral medication, although some clinical trials are designed as if this were an expected biological effect. Perhaps it is more important that these findings show that vitamin A supplementation does not seem to up-regulate the expression of HIV, a theoretical consideration raised by in vitro studies. Should clinical trials of vitamin A therapy to reduce mother-to-child transmission show a beneficial clinical effect, these studies suggest that the biological mechanism(s) would probably be mediated through some other means, such as reduction in chorioamnionitis or improvement of immune development in mother and infant.

\section{VITAMIN A AS THERAPY IN HUMAN IMMUNODEFICIENCY VIRUS INFECTION}

The community- and hospital-based clinical trials of vitamin A for child survival and treatment of acute measles provide compelling rationale for investigating the use of vitamin $\mathrm{A}$ as therapy in HIV infection. Epidemiological studies demonstrate that vitamin $\mathrm{A}$ deficiency is common in HIV-infected pregnant women, injection drug users in the inner city, and in adult populations in developing countries. In sub-Saharan Africa, where antiretroviral and prophylactic therapies may be prohibitively expensive, the optimization of micronutrient status may be among the affordable strategies available for potentially prolonging survival and reducing vertical transmission of HIV. Two recent clinical trials of vitamin A therapy for HIV-infected children suggest that vitamin A supplementation reduces diarrhoeal morbidity (Coutsoudis et al. 1995) and improves immunity (Hussey et al. 1996). Four clinical trials are currently in progress in Tanzania, South Africa, Malawi, and Zimbabwe to determine whether antenatal vitamin A supplementation can reduce vertical transmission and infant mortality. A large clinical trial in Uganda is addressing the question of whether periodic vitamin A supplementation can improve survival for HIVinfected children. A recent World Bank (1993) analysis has shown that vitamin A supplementation has the second-highest cost-benefit effect of forty-seven major health interventions studied. It remains to be determined whether vitamin A supplementation will have therapeutic benefit in reducing vertical transmission of HIV, infant mortality, and mortality of young children.

\section{REFERENCES}

Alvarez, J. O., Salazar-Lindo, E. Kohatsu, J., Miranda, P. \& Stephensen, C. B. (1995). Urinary excretion of retinol in children with acute diarrhea. American Journal of Clinical Nutrition 61, 1273-1276.

Bailey, J., Pluda, J. M., Foli, A., Saville, M. W., Bauza, S., Adamson, P. C., Murphy, R. F., Cohen, R. G., Broder, S. \& Yarchoan, R. (1995). Phase I/II study of intermittent all-trans-retinoic acid, alone and in 
combination with interferon alpha-2a, in patients with epidemic Kaposi's sarcoma. Joumal of Clinical Oncology 13, 1966-1974.

Beach, R. S., Mantero-Atienza, E., Shor-Posner, G., Javier, J. J., Szapocznik, J., Morgan, R., Sauberlich, H. E., Cornwell, P. E., Eisdorfer, C. \& Baum, M. K. (1992). Specific nutrient abnormalities in asymptomatic HIV-1 infection. AIDS 6, 701-708.

Beaton, G. H., Martorell, R., Aronson, K. J., Edmonston, B., McCabe, G., Ross, A. C. \& Harvey, B. (1993). Effectiveness of Vitamin A Supplementation in the Control of Young Child Morbidity and Mortality in Developing Countries. State-of-the-Art Nutrition Policy Discussion Paper no. 13. Geneva: ACC/SCN.

Birnbacher, T. (1928). Ueber den Frühlingsgipfel der epidemischen Mangelhemeralopie und die pathogenetische Bedeutung des Frühjahrs (On the springtime peak of epidemic hemeralopia and the pathogenic significance of spring). Wiener Klinische Wochenschrift 20, 698-700.

Buck, J., Ritter, G., Dannecker, L., Katta, V., Cohen, S. L., Chait, B. T. \& Hämmerling, U. (1990). Retinol is essential for growth of activated human B cells. Journal of Experimental Medicine 171, 1613-1624.

Campos, F. A. C. S., Flores, H. \& Underwood, B. A. (1987). Effect of an infection on vitamin A status of children as measured by the relative dose response (RDR). American Journal of Clinical Nutrition 46, 91-94.

Cantorna, M. T., Nashold, F. E., Chun, T. Y. \& Hayes, C. E. (1996). Vitamin A down-regulation of IFN-gamma synthesis in cloned mouse Th1 lymphocytes depends on the CD28 costimulatory pathway. Journal of Immunology 156, 2674-2679.

Christian, P., West, K. P. Jr, Khatry, S. K., Katz, J., Stoltzfus, R. J. \& Pokhrel, R. P. (1996). Epidemiology of night blindness during pregnancy in rural Nepal. Abstracts of the XVII International Vitamin A Consultative Group Meeting, Guatemala City, p.8. Washington, DC: International Life Sciences Institute.

Coodley, G. O., Coodley, M. K., Nelson, H. D. \& Loveless, M. O. (1993). Micronutrient concentrations in the HIV wasting syndrome. AIDS 7, 1595-1600.

Coutsoudis, A., Bobat, R. A., Coovadia, H. M., Kuhn, L., Tsai, W. Y. \& Stein, A. Z. (1995). The effects of vitamin A supplementation on the morbidity of children born to HIV-infected women. American Jourmal of Public Health 85, 1076-1081.

Coutsoudis, A., Broughton, M. \& Coovadia, H. M. (1991). Vitamin A supplementation reduces measles morbidity in young African children: a randomized, placebo-controlled, double-blind trial. American Journal of Clinical Nutrition 54, 890-895.

Dickover, R. E., Garratty, E. M., Herman, S. A., Sim, M.-S., Plaeger, S., Boyer, P. J., Keller, M., Deveikis, A., Stiehm, E. R. \& Bryson, Y. J. (1996). Identification of levels of maternal HIV-1 RNA associated with risk of perinatal transmission. Effect of matemal zidovudine treatment on viral load. Journal of the American Medical Association 275, 599-605.

Dixit, D. T. (1966). Night-blindness in the third trimester of pregnancy. Indian Journal of Medical Research 54, 791-795.

Ferre, F., Moss, R. B., Daigle, A., Richieri, S. P., Jensen, F. \& Carlo, D. J. (1995). Viral load in peripheral blood mononuclear cells as surrogate for clinical progression. Journal of the Acquired Immune Deficiency Syndromes and Human Retrovirology 10, Suppl. 2, 51-56.

Garbe, A., Buck, J. \& Hämmerling, U. (1992). Retinoids are important cofactors in T cell activation. Journal of Experimental Medicine 176, 109-117.

Greenberg, B. L., Semba, R. D., Vink, P. E., Schoenbaum, E. E., Farley, J. J. \& Weedon, J. (1996). Serum vitamin A and perinatal transmission of HIV among a cohort of HIV-infected women in the United States. Abstracts of the XI International Conference on AIDS, Vancouver, vol. 1, p. 367. Vancouver, Canada: XI International Conference on AIDS Society.

Hussey, G., Hughes, J., Potgieter, S., Kessow, G., Burgess, J., Beatty, D., Keraan, M. \& Carelse, E. (1996). Vitamin A status and supplementation and its effects on immunity in children with AIDS. Abstracts of the XVII International Vitamin A Consultative Group Meeting, Guatemala City, p. 6. Washington, DC: International Life Sciences Institute.

Hussey, G. D. \& Klein, M. (1990). A randomized, controlled trial of vitamin A in children with severe measles. New England Journal of Medicine 323, 160-164.

Karter, D. L., Karter, A. J., Yarrish, R., Patterson, C., Kass, P. H., Nord, J. \& Kislak, J. W. (1995). Vitamin A deficiency in non-vitamin-supplemented patients with AIDS: a cross-sectional study. Journal of Acquired Immune Deficiency Syndromes and Human Retrovirology 8, 199-203.

Kotler, D. P. \& Grunfeld, C. (1995). Pathophysiology and treatment of the AIDS wasting syndrome. In AIDS Clinical Review 1995/1996, pp. 229-275 [P. Volberding and M. A. Jacobson, editors]. New York: Marcel Dekker, Inc.

Landesman, S. H., Kalish, L. A., Burns, D. N., Minkoff, H., Fox, H. E., Zorrilla, C., Garcia, P., Fowler, M. G. Mofenson, L., Tuomala, R. \& Women and Infants Transmission Study (1996). Obstetrical factors and the transmission of human immunodeficiency virus type 1 from mother to child. New England Journal of Medicine 334, 1617-1623.

Nahlen, B. L., Chu, S. Y., Nwanyanwu, O. C., Berkelman, R. L., Martinez, S. A. \& Rullan, J. V. (1993). HIV wasting syndrome in the United States. AIDS 7, 183-188. 
Nduati, R. W., John, G. C., Richardson, B. A., Overbaugh, J., Welch, M., Ndinya-Achola, J., Moses, S., Holmes, K., Onyango, F. \& Kreiss, J. K. (1995). Human immunodeficiency virus type 1 -infected cells in breastmilk: association with immunosuppression and vitamin A deficiency. Journal of Infectious Diseases 172, 14611468.

Noback, C. R. \& Takahashi, Y. I. (1978). Micromorphology of the placenta in rats reared on marginal vitaminA-deficient diet. Acta Anatomica 102, 195-202.

Orchard, K., Lang, G., Harris, J., Collins, M. \& Latchman, D. (1993). A palindromic element in the human immunodeficiency virus long terminal repeat binds retinoic acid receptors and can confer retinoic acid responsiveness on a heterologous promotor. Joumal of Acquired Immune Deficiency Syndromes 6, 440-445.

Pilch, S. M. (1987). Analysis of vitamin A data from the Health and Nutrition Examination Surveys. Journal of Nutrition 117, 636-640.

Poli, G., Kinter, A. L., Justement, J. S., Bressler, P., Kehrl, J. H. \& Fauci, A. S. (1992). Retinoic acid mimics transforming growth factor $\beta$ in the regulation of human immunodeficiency virus expression in monocytic cells. Proceedings of the National Academy of Sciences USA 89, 2689-2693.

Quinn, T. C. (1996). Global burden of the HIV pandemic. Lancet 348, 99-106.

Ross, A. C. (1996). The relationship between immunocompetence and vitamin A status. In Vitamin A Deficiency: Health, Survival, and Vision, pp. 251-276 [A. Sommer and K. P. West Jr, editors]. New York: Oxford University Press.

Ross, A. C. \& Ternus, M. E. (1993). Vitamin A as a hormone: Recent advances in understanding the actions of retinol, retinoic acid, and beta carotene. Journal of the American Dietetic Association 93, 1285-1290.

Rwangabwoba, J. M., Humphrey, J., Coberly, J., Moulton, L., Desormeaux, J. \& Halsey, N. A. (1996). Vitamin A status and development of tuberculosis and/or mortality. Abstracts of the XI International Conference on AIDS, Vancouver vol. 2, p. 103. Vancouver, Canada: XI International Conference on AIDS Society.

Scrimshaw, N. S., Taylor, C. E. \& Gordon, J. E. (1968). Interactions of Nutrition and Infection. Geneva: WHO.

Semba, R. D. (1994). Vitamin A, immunity, and infection. Clinical Infectious Diseases 19, 489-499.

Semba, R. D. (1997). An overview of the potential role of vitamin A in mother-to-child transmission of HIV-1. Acta Paediatrica (In the Press).

Semba, R. D., Caiaffa, W. T., Graham, N. M. H., Cohn, S. \& Vlahov, D. (1995a). Vitamin A deficiency and wasting as predictors of mortality in HIV-infected injection drug users. Journal of Infectious Diseases 171, 1196-1202.

Semba, R. D., Graham, N. M. H., Caiaffa, W. T., Clement, L. \& Vlahov, D. (1993a). Increased mortality associated with vitamin A deficiency during HIV-1 infection. Archives of Internal Medicine 153, 2149-2154.

Semba, R. D., Miotti, P. G., Chiphangwi, J. D., Liomba, G., Yang, L. P., Saah, A., Dallabetta, G. \& Hoover, D. R. (1995b). Infant mortality and maternal vitamin A deficiency during HIV infection. Clinical Infectious Diseases 21, 966-972.

Semba, R. D., Miotti, P., Chiphangwi, J., Saah, A., Canner, J., Dallabetta, G. \& Hoover, D. R. (1994). Maternal vitamin A deficiency and mother-to-child transmission of HIV-1. Lancet 343, 1593-1597.

Semba, R. D., Muhilal, Scott, A. L., Natadisastra, G., Wirasasmita, S., Mele, L., West, K. P. Jr \& Sommer, A (1992). Depressed immune response to tetanus in children with vitamin A deficiency. Journal of Nutrition 122, 101-107.

Semba, R. D., Muhilal, Ward, B. J., Griffin, D. E., Scott, A. L., Natadisastra, G., West, K. P. Jr \& Sommer, A. $(1993 b)$. Abnormal T-cell subset proportions in vitamin A-deficient children. Lancet 341, 5-8.

Semba, R. D., Park, S. W., Royal, W. \& Griffin, D. E. (1996). Vitamin A deficiency and T-cell subpopulations in HIV-infected adults. Nutrition Research 16, 915-923.

Sidell, N., Chang, B. \& Bhatti, L. (1993). Upregulation by retinoic acid of interleukin-2-receptor mRNA in human T lymphocytes. Cellular Immunology 146, 28-37.

Silveira, S., Vannucchi, H., Jordão, A. Jr \& Figueiredo, J. F. C. (1996). Does urinary retinol excretion contribute to hypovitaminosis $\mathrm{A}$ in HIV-1-infected individuals and in patients with AIDS? Abstracts of the XI Intermational Conference on AIDS, Vancouver, vol. 2, p. 292.

Smith, F. R. \& Goodman, D. S. (1971). The effects of diseases of the liver, thyroid, and kidneys on the transport of vitamin A in human plasma. Journal of Clinical Investigation 50, 2426-2436.

Smith, F. R., Goodman, D. S., Arroyave, G. \& Viteri, F. (1973). Serum vitamin A, retinol-binding protein, and prealbumin concentrations in protein-calorie malnutrition. II. Treatment including supplemental vitamin A. American Journal of Clinical Nutrition 26, 982-987.

Sommer, A., Katz, J. \& Tarwotjo, I. (1984). Increased risk of respiratory disease and diarrhea in children with preexisting mild vitamin A deficiency. American Journal of Clinical Nutrition 40, 1090-1095.

Sommer, A., Tarwotjo, I., Hussaini, G. \& Susanto, D. (1983). Increased mortality in children with mild vitamin A deficiency. Lancet ii, 585-588.

Stephensen, C. B., Alvarez, J. O., Kohatsu, J., Hardmeier, R., Kennedy, J. I. Jr \& Gammon, R. B. Jr (1994). Vitamin $A$ is excreted in the urine during acute infection. American Journal of Clinical Nutrition 60, 388-392.

Tang, A. M., Graham, N. M. H., Kirby, A. J., McCall, L. D., Willett, W. C. \& Saah, A. J. (1993). Dietary micronutrient intake and risk of progression to acquired immunodeficiency syndrome (AIDS) in human 
immunodeficiency virus type 1 (HIV-1)-infected homosexual men. American Journal of Epidemiology 138, 937-951.

Temmerman, M., Nyong'o, A. O., Bwayo, J., Fransen, K., Coppens, M. \& Piot, P. (1995). Risk factors for mother-to-child transmission of human immunodeficiency virus-1 infection. American Joumal of Obstetrics and Gynecology 172, 700-705.

The Vitamin A and Pneumonia Working Group (1995). Potential interventions for the prevention of childhood pneumonia in developing countries: a meta-analysis of data from field trials to assess the impact of vitamin A supplementation on pneumonia morbidity and mortality. Bulletin of the World Health Organization 73, 609619.

Turpin, J. A., Vargo, M. \& Meltzer, M. S. (1992). Enhanced HIV-1 replication in retinoid-treated monocytes: retinoid effects mediated through mechanisms related to cell differentiation and to a direct transcriptional action on viral gene expression. Journal of Immunology 148, 2539-2546.

Vlahov, D., Anthony, J. C., Muñoz, A., Margolick, J. B., Nelson, K. E. \& Polk, B. F. (1991). The ALIVE study, a longitudinal study of HIV-1 infection in intravenous drug users: description of methods and characteristics of participants. Journal of Drug Issues 21, 755-771.

Wiedermann, U., Hanson, L. A., Holmgren, J., Kahu, H. \& Dahlgren, U. I. (1993). Impaired mucosal antibody response to cholera toxin in vitamin A-deficient rats immunized with oral cholera vaccine. Infection and Immunity 61, 3952-3957.

World Bank (1993). World Bank Reports 1993: Investing in Health. New York: Oxford University Press.

Zhao, Z. \& Ross, A. C. (1995). Retinoic acid repletion restores the number of leukocytes and their subsets and stimulates natural cytotoxicity in vitamin A-deficient rats. Joumal of Nutrition 125, $2064-2073$. 